\title{
The Institutional Approach in Economic Geography: an Applicative View
}

\author{
Simon Kušar
}

The institutional approach in economic geography developed as part of a broader cultural shift in economic geography in the 1990s. It highlights the importance of formal and informal institutions, technology, institutional embeddedness, and historical lock-in for understanding how development takes place in regions. Although these institutional theoretical concepts have been used primarily for explaining interregional differences in economic development, they soon became interesting as a theoretical basis for the development of innovative concepts in regional planning and policy. This article presents the applicative value of the institutional approach in economic geography in the field of regional planning and development. Further on, practical lessons are presented from a case study of the location of a greenfield investment by Carthago in Odranci near Murska Sobota, Slovenia. Finally, selected limitations of the institutional approach in regional planning are discussed.

Key words: economic geography, institutionalism, regional planning, regional development, Slovenia

\section{Institucionalni pristup u ekonomskoj geografiji: aplikativni pristup}

Institucionalni se pristup javio u ekonomskoj geografiji kao dio većeg kulturnog pomaka u ekonomskoj geografiji tijekom 1990-ih. Naglašava važnost formalnih i neformalnih institucija, tehnologije, ukorijenjenosti institucija te povijesne povezanosti u razumijevanju regionalnog razvoja. Iako se svi ti institucionalni teorijski koncepti rabe prvenstveno u objašnjavanju međuregionalnih razlika u ekonomskom razvoju, postali su zanimljivi i kao teorijski temelj za razvoj inovativnih koncepata regionalnog planiranja i politika. Ovaj članak bavi se mogućnostima primjene institucionalnog pristupa u ekonomskoj geografiji na polju regionalnog planiranja i razvoja. Predstavljena su i praktična saznanja iz studije slučaja greenfield ulaganja tvrtke Carthago u Odrancima kraj Murske Sobote u Sloveniji. Naposljetku, sagledavaju se i određena ograničenja institucionalnog pristupa u regionalnom planiranju.

Ključne riječi: ekonomska geografija, institucionalizam, regionalno planiranje, regionalni razvoj, Slovenija 


\section{INTRODUCTION}

Post-modern development of economic geography brought not only a parallel use of traditional theoretical approaches but also many new ones. Following a cultural shift, new approaches often emphasise the social and cultural dimensions of the economy (Cumbers at al., 2003). One of the elements of this cultural shift was also an institutional shift (Martin, 2005) highlighting the institutional dimension of the economy. Economic geography also experienced the development of an institutional approach.

Although the institutional approach in economic geography is often criticised for depending too much on theoretical concepts from economic sociology, institutional and evolutionary economics (Martin, 2005), for neglecting spatial categories (Kušar, 2008), for focusing too much on the regional level (Cumbers at al., 2003), and for lacking evidence from the field (Rodrigues-Pose, 1998), Barnes and his colleagues (2004) are convinced that the institutional approach in economic geography can serve as a strong theoretical and methodological background for studying the geographical dimensions of economic activities. Even more, they see the institutional approach in economic geography as the most appropriate contemporary economic-geographical approach by stating that"to practice institutionalism is to practice economic geography" (Barnes et al., 2004, 16).

The article explores the possible range of the institutional approach in economic geography for regional planning. But first, basic characteristics of the institutional approach in economic geography are highlighted, including key theoretical concepts. Later, its application in regional planning and policy is explained.

The applicative role of the institutional approach in economic geography in regional and spatial planning is also examined through a case study that examined the location of a greenfield foreign direct investment by Carthago from Germany in Odranci, in the Pomurska development region of Slovenia. Finally, some limitations of institutional theoretical concepts in regional planning are highlighted, together with lessons that were learnt from the case study.

\section{INSTITUTIONAL SHIFT AND THE INSTITUTIONAL APPROACH IN ECONOMIC GEOGRAPHY}

The institutional approach in economic geography developed after the institutional shift in the social sciences in the 1990s. The institutional shift rejected neoclassical approaches that were regarded as unrealistic and one-sided, and focused too much on the economic dimension of everyday life. Institutionalists are convinced that individuals are not "Homo economicus" - rational and narrowly self-interested actors following only the goals of their material well-being. On the contrary, institutional approaches highlight the importance of social institutions that influence and shape the economy. Although this theory is very close to political economy, it differs from political-economic theories by assessing the role of institutions in a specific direction. In institutionalism, institutions are not just entities separate from the economy, but rather an integral part of the economy. Even more: the economy is embedded in social relations and as such, it is part of wider social processes (Martin, 2005). Hudson (2005) stated that institutions even enable the operation of the economy. 
The key theoretical concept in the institutional approach is the institution. Institutions are the system of rules, conventions, values, norms, laws, beliefs, and thoughts (Helmke and Levitsky, 2004) that shape interaction between people (North, 1990). Institutions are both formal and informal. Formal institutions are legally defined rules, regulations, and conventions (Pike at al., 2006). Informal institutions are values and norms that are part of the culture. Usually, informal institutions are unwritten rules developed outside of the formal system, but they enable everyday communication and relations between people (North, 1990). Formal and informal institutions are linked. Formal institutions must be deeply rooted in informal institutions, otherwise formal institutions lack legitimacy. If formal institutions are changed, informal institutions change as well. But the process of changing informal institutions is usually extremely slow (North, 1990). Differences in the rate of change of formal and informal institutions can cause specific spatial problems, often resulting in the formation of problem regions.

The institutional shift was strongly influenced by traditional institutional economics. The original idea was developed by Veblen at the beginning of the $20^{\text {th }}$ century. He was convinced that institutions influence the development of human thoughts and actions, and that they are developing under the influence of technology (Barnes, 1999). These ideas have never been influential in mainstream economics as a discipline, but they have attracted strong attention from other social sciences, especially after the second half of the 1980s.

Veblen's institutionalism has strongly influenced the development of evolutionary economics. Evolutionary economics highlights the developmental dimension of the economy. For example, the theoretical concept of "path dependence" describes the role of past decisions regarding technology and institutions in contemporary state-of-the-art of technology, enterprises and regions (Harrington at al., 1999). North (1990) thinks that contemporary conditions in the society and the economy cannot be understood without having knowledge about the past development of institutions. When technology and institutions are selected, they often lead to "lock-in" into the selected trajectory of knowledge, thoughts and development, making it impossible to follow new ideas and development concepts (Hayter, 2004).

Economic sociology offered intellectual propositions for the development of an institutional approach in economic geography as well. Economic sociology developed the theoretical concept of "embeddedness". It is used for interpretation of the formation of social relations between people. The economy is, as a part of wider social processes, embedded in those social relations. Originally, embeddedness is not a spatial concept. It is defined just through social, political and economic processes (Hayter, 2004).

The institutional shift is very important for the contemporary development of economic geography. However, Martin (2005) warns that talking about institutional economic geography is too optimistic. He believes that, due to many theoretical difficulties and unresolved issues regarding new theoretical and methodological elements, it is too early to talk about institutional economic geography. Instead, he suggests using the expression "the institutional approach in economic geography."

The starting point for the institutional approach in economic geography is the notion that differences in economic development between regions are actually the result of 
interregional differences in institutions. Since formal and informal institutions (rules, laws, conventions, norms and values) are place-specific characteristic of the society, they should be of considerable interest to geographers as well. Therefore, the institutional approach in economic geography tries to answer the question, "to what extent and in what ways are the processes of geographically uneven capitalist economic development shaped and mediated by the institutional structures?" (Martin, 2005, 79).

Although many theoretical concepts in the institutional approach in economic geography were taken from traditional institutional economics, evolutionary economics and economic sociology, geographers also played an important role in developing institutionalism.

Geographers added a spatial dimension to institutional theoretical concepts; for example, they introduced the spatial dimension of embeddedness. Geographical embeddedness is represented through the spatial proximity of enterprises. It enables regular formal and informal contacts that stimulate trust, co-operation and knowledge transfer. Conceptions of path dependence and lock-in have their spatial dimensions as well: institutions are characterised by path dependence that is place-specific (Martin, 2005).

The institutional approach in economic geography has also expanded the notion of institutions to institutions as organisations (Pike at al., 2006). Special attention is paid to region-specific organisations, for example regional development agencies (Cumbers at al., 2003).

Economic geographers developed new theoretical institutional concepts, like institutional space, institutional thickness and untraded interdependencies. "Institutional space" is a specific geographical area in which a specific organisation exercises its role. There are many institutional spaces arranged at different spatial levels (Martin, 1995). The concept of "institutional thickness" was developed by Amin and Thrift in 1995. The concept includes four key elements. There must be a large number of institutions in a region with a high level of mutual connectedness, but low level of conflict. These three elements are the starting point for the formation of mutual consciousness that leads toward their cooperation on collective strategies and projects (Martin, 2005). In 1997, Storper (1997) developed the concept of "untraded interdependencies". Enterprises and organisations become in the course of time "tied" to specific areas due to untraded interdependencies. "Untraded interdependencies take the form of conventions, informal rules and habits that coordinate economic actors under conditions of uncertainty. These relations constitute region-specific assets in production" (Storper, 1997, 5).

Economic geographers gave proof of institutional theory from case studies that highlighted the role of regional culture, co-operation and trust among various organisations in shaping economically successful regions. The most well-known are the studies on Silicon Valley and its comparison to Route 128 near Boston conducted by Saxenian in 1994, on the Third Italy (Poire and Sabel), on an area of machine and automobile manufacturing in Baden-Württemberg (Gertler), and on the Ruhr area conducted by Grabher (Kušar, 2008). All these practical experiences influenced the development of new innovative instruments in regional planning. 


\section{APPLICATION OF THE INSTITUTIONAL APPROACH IN ECONOMIC GEOGRAPHY: REGIONAL PLANNING AND DEVELOPMENT}

The institutional approach in economic geography highlights the role of organisations, geographical proximity, networking, embeddedness, development trajectories of regions, institutions and technology. Although these institutional theoretical concepts had been used primarily for explaining interregional differences in economic development (Pike at al., 2006), they soon became interesting as a theoretical basis for the development of new concepts in regional planning and policy. Planners are trying to imitate practical experiences from economically successful regions described by geographers by fostering an institutional basis, region-specific organisations, networking, entrepreneurship, development and diffusion of tacit knowledge, learning and technological innovations (Cumbers at al., 2003).

This new regional planning and policy approach seems to be compatible with recent developments in planning theory. For example, Friedmann's social learning highlights the role of development trajectories, and Healey's collaborative planning shares its enthusiasm for the importance of building institutional capacity with the institutional approach in economic geography as well (Wheeler, 2004).

The following paragraphs provide a brief analysis of theoretical concepts from the institutional approach in economic geography that have been applied in regional planning and policy.

1. Institutions. Institutions are a focal point of the institutional approach in economic geography. The economy is strongly dependent on formal and informal institutions. Since institutions are place-specific and difficult to diffuse, they can be understood as an endogenous development factor responsible for the economic development or stagnation of regions. Therefore, appropriate institutional structure is of high importance for the successful promotion of regional development. Regions with a high level of trust are capable of developing innovations. They have better prospects for adapting to new development challenges (Saxenien, 1994).

2. Embeddedness. This theoretical concept was taken originally from economic sociology, but geographers introduced its spatial dimension. If the economy is embedded in social relations, then trust, collaboration and conventions have a key role in promoting regional development, while they enable exchange of knowledge and solving various challenges (Martin, 2005; Saxenien, 1994). Regional policy needs to introduce platforms that stimulate co-operation between different stakeholders in a formal and informal way. The latter might be difficult when regional planning is institutionally formalised, but there are informal networks of entrepreneurs in every region that can be used for increasing cohesion in the region. The geographical notion of spatial embeddedness also highlights the importance of geographical proximity. Therefore, regional agglomerations seem to be the right answer while planning spatial dimensions of regional development.

3. Geographical proximity. Geographical proximity stimulates formal and informal interaction between enterprises and other development stakeholders in a region (government and its offices, local and regional administration, development agencies, universities, 
technological centres, financial organisations, economic chambers, trade unions, nongovernmental organisations) resulting in trust, co-operation and knowledge exchange. Geographical proximity increases the efficiency of learning and developing innovations (Cumbers at al., 2003) that are recognised as a key element for economic breakthrough.

4. Development of the economy - evolutionism. Institutionalists are convinced that the economy is a social construct that is developing. For successful promotion of regional development it is necessary to understand that the production system is a result of historical processes. Therefore, it is difficult to change regional institutions (Saxenien, 1994).

5. Geographical diversity. There are important spatial differences in the characteristics of institutions; therefore, the institutional context differs between different regions causing differences in development dynamics (Pike at al., 2006). Regional policy instruments exercised in a successful region cannot be universally applicable in other regions. Every region needs to develop its own regional development approach.

6. Technology. According to institutional theory, technology stimulates institutional changes. Viewed from the regional planning and policy standpoint, innovations are necessary when trying to achieve sustainable economic and regional development (Martin, 2005).

7. Networking. Co-operation between companies reduces risks. Therefore, production networks are an organisational form that enables development (Storper, 1997). Regional development strategies should pay special attention to complementing already existing production networks or building new ones, for example, with foreign direct investment that fits well into the existing production structure.

8. Institutional thickness. This is a theoretical concept developed by economic geographers. It is defined through a number of organisations in a region with a high degree of mutual connectedness. Institutional thickness stimulates mutual co-operation on different projects. A mutually connected regionally specific organisational structure is a prerequisite for successful economic growth and regional development (Barnes, 1999).

If originating from institutional theoretical concepts, regional policy should (Kušar, 2008):

1. develop appropriate institutional thickness at the regional level that serves as an institutional precondition for building trust among all stakeholders in the development process, creating untraded interdependencies and stimulating technological development and networking;

2. stimulate and coordinate collaboration between companies, between companies and the public sector and between local authorities;

3. convert global-local dynamics in the appropriate land use pattern and activities that would form the basis for the development of local production and consumption systems;

4. stimulate formation of informal networks that would enable the development of tacit knowledge, increase trust between stakeholders and reduce uncertainties in the production process; and, 
5. develop an institutional system that would define a clear conceptual framework in which the regional economy operates.

Contemporary regional policy tries to increase the innovation capabilities of regions and to strengthen co-operation between different stakeholders; therefore, it includes some of the suggested concepts from the institutional approach in economic geography. To be more illustrative about the strength and the role of theoretical concepts from the institutional approach in economic geography, a case study is presented in the next section that tries to define which above mentioned elements have been noticed during the location procedure of a foreign direct investment in the Pomurska development region in Slovenia.

Tab. 1 Application of institutional theoretical concepts in regional planning and development

Tab. 1. Primjena institucionalnih teorijskih koncepata u regionalnom planiranju i razvoju

\begin{tabular}{|l|l|}
\hline Theoretical concept & $\begin{array}{l}\text { Context used for creation of innovative regional policy in- } \\
\text { struments }\end{array}$ \\
\hline Institutions & $\begin{array}{l}\text { Endogenous development factor responsible for the develo- } \\
\text { pment or stagnation of regions: appropriate institutional struc- } \\
\text { ture is important for the promotion of regional development. }\end{array}$ \\
\hline Embeddedness & $\begin{array}{l}\text { Trust, collaboration and conventions have a key role in promo- } \\
\text { ting regional development. Regional policy needs to introduce } \\
\text { platforms that stimulate co-operation among different stake- } \\
\text { holders in formal and informal ways: regional agglomerations } \\
\text { are highly important. }\end{array}$ \\
\hline Geographical proximity & Increases efficiency of learning and developing innovations. \\
\hline Evolutionism & $\begin{array}{l}\text { Production system is a result of historical processes: regional } \\
\text { institutions are difficult to change. }\end{array}$ \\
\hline Geographical diversity & $\begin{array}{l}\text { Institutional context differs between different regions. Every } \\
\text { region has to develop its own development approach. }\end{array}$ \\
\hline Technology & Innovations are necessary for successful regional development. \\
\hline Networking & $\begin{array}{l}\text { Production networks are an organisational form that enables } \\
\text { development. }\end{array}$ \\
\hline Institutional thickness & $\begin{array}{l}\text { Mutually connected regional specific institutional structure is } \\
\text { a prerequisite for regional development. }\end{array}$ \\
\hline
\end{tabular}

Source: Adapted from Kušar, 2008.

\section{CASE STUDY: CARTHAGO GREENFIELD INVESTMENT IN ODRANCI, IN THE POMURSKA DEVELOPMENT REGION, SLOVENIA}

This part of the article brings some evidence from the field about the importance of the institutional approach in economic geography and its application in regional planning. When conducting traditional economic geographical (neutrally-observed) research on the location of a foreign direct greenfield investment by the Carthago company in Odranci, 
special attention was given to examining the role of planning organisations and institutions. Findings were later interpreted using the framework of the institutional approach. The case study is taken from Kušar (2008).

Carthago Reisemobilbau GmBH from Ravensburg (Germany) manufactures luxury motor homes. Due to high labour costs and spatial limitations at current production sites, the management of Carthago decided to relocate production facilities to another country. Although the original intention was to relocate to the Czech Republic, in the end Odranci in the Pomurje development region in the northeastern part of Slovenia was selected.

There were a number of reasons for this decision. Not only hard location factors, but also policy instruments and other institutional dimensions played a significant role in choosing Odranci as a place for the investment.

Location factors that favoured the Odranci site were:

1. Accessibility. Odranci is located near the Pomurska highway, which is part of the fifth European corridor.

2. Labour. The Pomurje development region is the least developed region in Slovenia, hence there are plenty of unemployed workers who are willing to work in a traditional production sector.

3. Premises. The Municipality of Odranci offered an industrial zone that was fully equipped with infrastructure at an affordable price.

4. Personal preferences. The investor did not want to locate his factory in a town in order to avoid spatial limitations experienced at the original site in Germany. The investor was also enthusiastic about the hospitality of locals and the mayor.

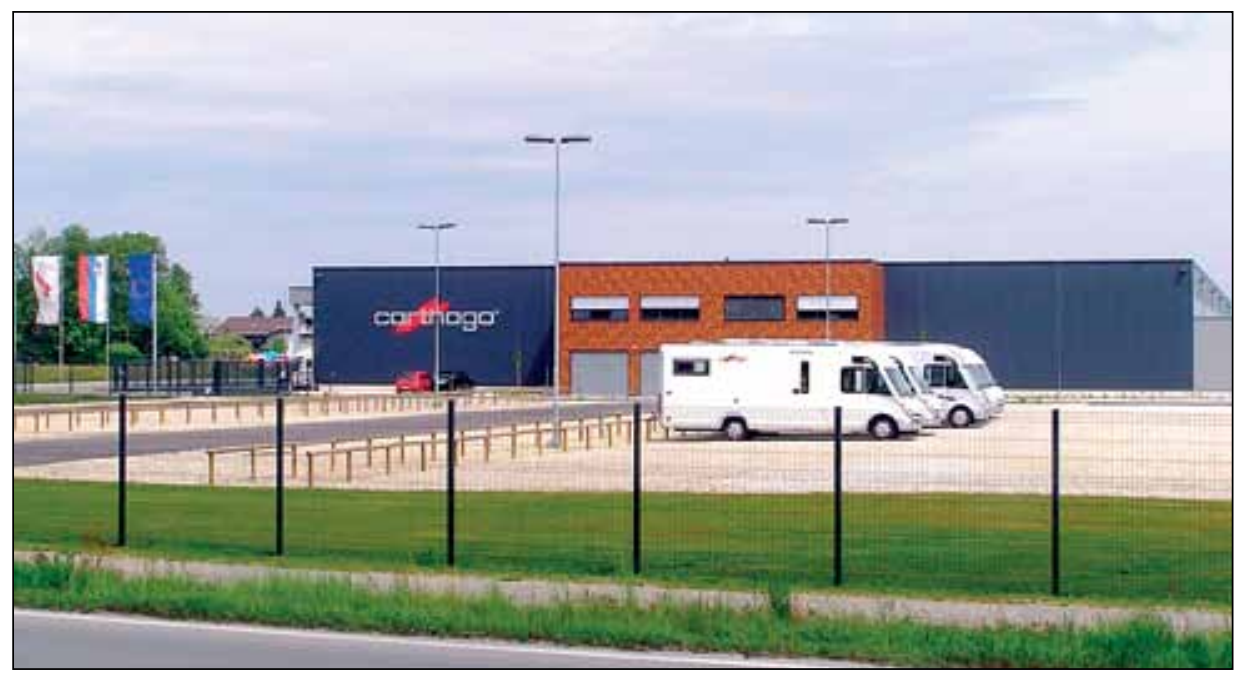

Fig. 1 Carthago plant in Odranci, Slovenia

Sl. 1. Tvornica Carthago u Odrancima, Slovenija 
However, it is necessary to point out some institutional factors as to why Carthago located in Odranci. The investment was successfully realised thanks in large part to Slovenia's national industrial policy: if the investor had not been given a direct financial incentive of $€ 1.2$ million (one fifth of the estimated investment costs), the investment project would not have been realised in Slovenia at all. Instruments of the current national regional policy were used to equip the Kamenice industrial zone near Odranci with infrastructure. The regional development agency helped with technical advice and with coordination between the investor, the municipality and national planning organisations.

The Municipality of Odranci had an especially important role. Actually, it acted as a key formal planning organisation. Namely, long before the Carthago story, Odranci submitted a strategic decision to promote development of the manufacturing sector and not tourism, unlike other municipalities in the area. Promotion of manufacturing included ensuring spatial preconditions for the development of manufacturing activities and upgrading the infrastructure. After the locating procedure began, the mayor and the municipal administration were in constant contact with the investor, helping him through various stages of the formal planning system (obtaining the necessary permits, preparing planning documents for the project, and applying for funding from national planning organisations). The industrial zone of Kamenice was further expanded. The mayor also used his (political) influence to overcome obstacles set by other organisations.

There were also informal institutions: norms, values and habits of the local population, their knowledge, skills and tradecraft tradition that stimulated this development.

Today, Carthago in Odranci owns an 8,000-square metre production facility. In 2008, 35 workers were employed, but this number had increased to 170 by the end of 2010 . The production capacity is 18-24 luxury motor homes per week. A new production building is being built and there are plans to double the production in 2011. The Carthago branch plant is responsible for the production, while development and sales are still located at the main site in Ravensburg. There are plans to move the design of the new generation of motor homes to Odranci as well.

\section{APPLICATION OF THE INSTITUTIONAL APPROACH IN ECONOMIC GEOGRAPHY: LESSONS TO BE LEARNT}

The application of institutional theoretical concepts for planning purposes encounters many difficulties. For example, stimulating institutional thickness just by setting up new local and regional organisations is not a sufficient precondition for the successful development of regions, for two reasons. Firstly, the concept includes not just the number of organisations but most importantly, their formal and informal connections. Secondly, it is questionable whether regions with high institutional thickness are successful due only to the presence of many organisations. Furthermore, emphasising geographical proximity is also questionable if this approach is oriented too much towards the stimulation of already developed economic centres to the detriment of the peripheral parts of regions. There are concerns that research on the role of institutional factors in stimulating regional development is too abstract. The application of the institutional approach in economic geography in regional planning and policy rests mainly on the cases of successful regions, but there is a deficit of case studies explaining the role of institutions in less developed regions. 
As is evident from the Carthago case study, institutional thickness at the regional level can play an important role in implementing regional development projects, but the institutional approach should examine the role of the state at stimulating regional development in more detail as well. The importance of the evolutionary concept is evident from the development strategy of Odranci, which emphasised the development of manufacturing instead of tourism. Informal institutions and their spatial variations were important, as well, since the values, social norms and customs of the locals acted as a catalyst for the development impulse that was studied. Local entrepreneurs will collaborate with Carthago; therefore, new production networks will be formed that will facilitate further development of manufacturing in the municipality.

It was not possible to study all the possible applicative dimensions of the institutional approach in economic geography through the case study. However, following suggestions for application of institutional theoretical concepts in regional policy, it was observed that in the case of Carthago:

1. appropriate institutional thickness at the regional level was important to fulfil expectations of the investor and enabled successful realisation of the investment;

2. trust and collaboration between the regional development agency, municipality, national planning offices and the investor offered the platform for exchange of knowledge and finding solutions to various challenges during the formal planning procedures;

3. appropriate land use planning on the municipal level offered new dimension to the development of local production and consumption systems;

4. informal networks between the mayor, municipal administration, regional planning officials, public servants and local residents increased trust between stakeholders and reduced uncertainties in the planning process;

5. unfortunately, the unclearly defined regional and national institutional system caused additional uncertainties in the locating procedure; therefore, further organisational improvements on the regional and national level need to be made.

Since traditional location factors still play important role in regional development and since institutional theoretical concepts are still experiencing many difficulties, regional planning should not be restricted only to tools that are theoretically based on the institutional approach in economic geography. Regional policy instruments with institutional dimensions are needed, but they should be used in coordination with traditional instruments of the regional policy, such as allocation of funds to problem regions, tax-revenues, subsidies to various economic sectors and infrastructure investments. 


\section{REFERENCES}

Barnes, T. J., 1999: Industrial geography, institutional economics and Innis, in: The New Industrial Geography: Regions, Regulations and Institutions (eds. Barnes, T. J., Gertler, M. S.), Routledge, London, New York, 1-20.

Barnes, T. J., Tickell, A., Peck, J., Sheppard, E. 2004. Paradigms Lost, in: Reading Economic Geography (eds. Barnes, T. J., Tickell, A., Peck, J., Sheppard, E.), Blackwell Publishing, Malden, 13-18.

Cumbers, A., MacKinnon, D., McMaster, R., 2003: Institutions, power and space. Assessing the limit to institutionalism in economic geography, European Urban and Regional Studies 10 (4), 325-342.

Harrington, J. W., Barnes, T. J., Glasmeier, A. K., Hanink, D. M., Rigby, D. L., 1999: Economic Geography: Reconceiving»The Economic« and»The Region«. http://72.14.221.104/search?q=cache:IFXo_v-cRjEJ:geog. uconn.edu/aag-econ/econ_reg.pdf $+\% 2$ Binstitutionalism\%2Bgeography\&hl $=$ sl\&gl=si\&ct $=\mathrm{clnk} \& \mathrm{~cd}=34$ (22.8.2006.)

Hayter, R., 2004: Economic geography as dissenting institutionalism: The embeddedness, evolution and differentiation of regions. Geografiska Annaler B (Human Geography) 86 (2), 95-115.

Helmke, G., Levitsky, S., 2004: Informal Institutions and Comparative Politics: A Research Agenda. http://www.people.fas.harvard.edu/ levitsky/

researchpapers/informal-institutions.pdf (22.8.2006.)

Hudson, R., 2005: Economic Geographies. Circuits, Flows and Spaces, Sage Publications, London.

Kušar, S., 2008: Vloga prostorskega planiranja pri lociranju proizvodnih dejavnosti v Sloveniji: doktorska disertacija, Oddelek za geografijo Filozofske fakultete Univerze v Ljubljani, Ljubljana.

Martin, R., 2005: Institutional Approaches in Economic Geography, in: A Companion to Economic Geography (eds. Sheppard, E., Barnes, T. J.), Blackwell Publishing, Malden, 77-94.

North, D. C., 1990: Institutions, institutional change and economic performance, Cambridge University Press, Cambridge.

Pike,A., Rodriguez-Pose,A., Tomaney, J., 2006: Local and Regional Development, Routledge, London, New York.

Rodriguez-Pose, A., 1998: The Dynamics of Regional Growth in Europe: Social and Political Factors, Clarendon Press, Oxford.

Saxenien, A., 1994: Regional Advantage: Culture and Competition in Silicon Valley and Route 128, Harvard University Press, Cambridge.

Storper, M., 1997: The Regional World: Territorial Development in a Global Economy, The Guilford Press, New York, London.

Wheeler, S. M., 2004: Planning for Sustainability: Creating liveable, equitable and ecological communities, Routledge, London, New York.

Received (Primljeno): $2010-12-28$

Accepted (Prihvaćeno): $2011-03-18$

Simon Kušar

Department of Geography

Faculty of Arts

University of Ljubljana

SI-1000 Ljubljana, Aškerčeva 2

simon.kusar@ff.uni-lj.si 
